\title{
PERSEPSI MAHASISWA AKUNTANSI DAN MAHASISWA MANAJEMEN TERHADAP ETIKA PENYUSUNAN LAPORAN KEUANGAN DAN MANAJEMEN LABA
}

\author{
Fatma Ali Awad Alkatiri ${ }^{l)}$ Akbar Yusuf ${ }^{2)}$ Fitriningsih Amalo ${ }^{2)}$ \\ ${ }^{1)}$ Aumni Program Studi Akuntansi Universitas Muhammadiyah Kupang \\ ${ }^{2)}$ Dosen Tetap Program Studi Akuntansi Universitas Muhammadiyah Kupang
}

\begin{abstract}
ABSTRAK
Penelitian ini bertujuan untuk mengetahui persepsi dan perbedaan persepsi antara mahasiswa akuntansi dan mahasiswa manajemen terhadap etika penyusunan laporan keuangan dan manajemen laba. Penelitian ini dilakukan pada Universitas Muhammadiyah Kupang. Data yang digunakan dalam penelitian ini data primer. Populasi dalam penelitian ini adalah mahasiswa akuntansi dan mahasiswa manajemen. Teknik pengambilan sampel dalam penelitian ini menggunakan purposive sampling. Skala pengukuran yang digunakan adalah skala likert, dengan jumlah responden 120 orang. Pengujian data dilakukan dengan non parametric yaitu mann whitney u-test dan pengujian anova yaitu one way anova dengan menggunakan bantuan SPSS for windows 21. Hasil empiris membuktikan bahwa (1) persepsi mahasiswa akuntansi dan mahasiswa manajemen terhadap etika penyusunan laporan keuangan dapat dikatakan baik (2) persepsi mahasiswa akuntansi dan mahasiswa manajemen terhadap manajemen laba dapat dikatakan baik (3) tidak terdapat perbedaan persepsi mahasiswa akuntansi dan mahasiswa manajemen terhadap etika penyusunan laporan keuangan (4) terdapat perbedaan persepsi mahasiswa akuntansi dan mahasiswa manajemen terhadap manajemen laba.
\end{abstract}

Kata kunci: etika penyusunan laporan keuangan, manajemen laba

\section{PENDAHULUAN}

Penyabab kebangkrutan dan keterpurukan pada perusahaan Enron Corporation, adalah editor, Arthur Andersen (satu dari lima perusahaan akuntansi terbesar) yang merupakan kantor dalam memanipulasi laporan keuangan sehingga merugikan berbagai pihak baik pihak eksternal maupun pihak internal enron telah melanggar etika dalam bisnis dengan tidak melakukan manipulasi-manipulasi terutama etika dalam penyusunan laporan sehingga menimbulkan manajemen laba guna menarik investor. Etika penyusunan laporan keuangan adalah aturan-aturan untuk mengatur tingkah laku seseorang atau kelompok dalam mempertanggungjawabkan tugasnya memberikan informasi kepada pengguna laporan keuangan dalam membuat keputusan Mahmud (2008). Scott dalam Yulianthi dan Fitriany (2005) bahwa manajemen laba merupakan pilihan kebijakan dan pengguna laporan keuangan. Manajemen laba adalah suatu tindakan untuk memanipulasi laporan keuangan yang sebenarnya agar dapat 
menyembunyikan kondisi perusahaan dari pihak-pihak pemegang saham sehingga tercapai tingkat laba yang diharapkan.

Kasus perusahaan besar diatas yang terlibat dalam praktik manajemen laba memberikan kesadaran tentang pentingnya peran dunia pendidikan dalam menciptakan sumber daya manusia yang cerdas dan bermoral. Pendidikan akuntansi pada jenjang strata satu (S1) pada umumnya hanya mengajarkan etika terkait profesi akuntan pada mata kuliah pengauditan (auditing). Padahal isu etika tidak hanya terkait pada masalah pengauditan, tapi juga berhubungan dengan penyusunan laporan keuangan. Kasus kecurangan akuntansi (accounting fraud) terjadi karena adanya praktik manajemen laba yang dilakukan dengan cara memanipulasi laporan keuangan. Oleh karena itu, anak didik (mahasiswa) perlu diperkenalkan tentang isu-isu etika yang terkait dengan penyusunan laporan keuangan (Wulandari dan Sularso 2002).

Beberapa penelitian mengenai mengenai sosialisasi kode etika profesi menyangkut manajemen laba pada mahasiswa akuntansi yang dilakukan oleh Clikeman dan Henning (2000) di salah satu universitas di Amerika yang menyimpulkan bahwa mahasiswa akuntansi lebih tidak menyetujui manajemen laba pada tahun-tahun akhir di bandingkan tahun-tahun awal penelitian. hal yang sama di lakukan di Inggris oleh Marriott dan Marriott (2003), mereka menyimpulkan bahwa mahasiswa akuntansi memiliki sikap positif menyangkut profesi akuntan pada tahun-tahun awal kuliah dan menurun secara signifikan pada tahun-tahun akhir masa perkuliahan. Di Indonesia penelitian yang dilakukan oleh Cahyani Siska Dewi (2013) hasil penelitian menyatakan bahwa terdapat perbedaan mahasiswa akuntansi dan mahasiswa manajemen, dimana mahasiswa akuntansi memiliki persepsi yang lebih besar mengenai etika penyusunan laporan keuangan, hal ini disebabkan karena pengetahuan yang dimiliki oleh mahasiswa akuntansi dengan mahasiswa manajemen berbeda, dari segi pengetahuan dan mata kuliah yang ditempuh mahasiswa akuntansi dan mahasiswa non akuntansi (mahasiswa manajemen).

Penelitian ini dimaksudkan untuk menilai efektivitas pendidikan akuntansi dan manajemen dalam menimbulkan tanggungjawab mahasiswa akuntansi dan mahasiswa manajemen terhadap pengguna laporan keuangan. Goa dan Thorne dalam Yulianti dan Fitriany (2005) mengatakan bahwa pendidikan akuntansi selama ini mengfokuskan pada dimensi pilihan kebijakan tetapi tidak memperhatikan nilai dan kredibilitas yang 
mempengaruhi pilihan tersebut, kemudian Goa dan thoren menyebutkan bahwa pada dasarnya akuntansi memilih tindakan berdasarkan pikiran mereka. Pendapat ini diperkuat oleh kiger dalam Yulianti dan Fitriany (2005) yang menyebutkan bahwa pendidikan akuntansi tidak difokuskan pada etika dalam subjek-subjek akademik melainkan pada sensitivitas etika itu sendiri, karena itulah pembentukan nilai-nilai moral dan etika dalam pola pikir seseorang akuntansi sangat penting dan hal ini dapat dicapai melalui sosialisasi nilai moral dan etika dalam pendidikan akuntansi secara memadai.

Berdasarkan latar belakang yang dikemukakan diatas maka yang menjadi tujuan penelitian ini adalah: 1) untuk mengetahui persepsi mahasiswa akuntansi dan manajemen terhadap etika penyusunan laporan keuangan. 2) untuk mengetahui persepsi mahasiswa akuntansi dan manajemen terhadap manajemen laba. 3) untuk mengetahui apakah terdapat perbedaan antara akuntansi dan mahasiswa manajemen terhadap etika penyusunan laporan keuangan. 4) untuk mengetahui apakah terdapat perbedaan antara mahasiswa akuntansi dan manajemen terhadap manajemen laba.

\section{TINJAUAN PUSTAKA DAN PENGEMBANGAN HIPOTESIS}

\section{Manajemen Laba}

Scott dalam Daito (2004) manajemen laba adalah intervensi manajemen dalam proses penyusunan laporan keuanganbagi pihak eksternal sehinggan dapat meratakan, menaikan dan menurunkan pelaporan laba, dimana manajemen dapat menggunakan kelonggaran penggunaan metode akuntansi, membuat kebijakan-kebijakan yang dapat mempercepat dan menunda biaya-biaya dan pendapatan, agar laba perusahaan lebih kecil atau lebih besar sesuai yang diharapkan. Sedangkan menurut Satyanugraha (2006) manajemen laba adalah tindakan untuk meningkatkan atau menurunkan pendapat perusahaan tanpa adanya kenaikan atau penurunan yang sebenarnya dari operasi perusahaan. Fitriani (2010) ada berbagai macam tujuan yang ingin dicapai oleh manajemen laba dalam pemrataan laba yaitu:

a. mencapai keuntungan;

b. untuk memberikan kesan baik dari pemilik dan kreditor terhadap kinerja manajemen;

c. mengurangi fluktuasi pada pelaporan laba dan mengurangi resiko;

d. untuk menghasilkan pertumbuhan profit yang stabil; 
e. untuk mejaga posisi atau kedudukan mereka dalam perusahaan.

Berbagai definisi diatas dapat disimpulkan manajemen laba adalah suatu tindakan untuk memanipulasi laporan keuangan yang sebenarnya agar dapat menyembunyikan kondisi perusahaan dari pihak-pihak pemegang saham sehingga tercapai tingkat laba yang diharapkan.

\section{Etika Dalam Penyusunan Laporan Keuangan}

Menurut IAI (2007), Laporan keuangan merupakan bagian dari proses pelaporan keuangan. Tujuan laporan keuangan adalah menyediakan informasi yang menyangkut posisi keuangan, kinerja serta perubahan posisi keuangan suatu perusahaan yang bermanfaat bagi sejumlah besar dalam pengambilan keputusan ekonomi. Laporan keuangan disusun untuk tujuan memenuhi kebutuhan bersama sebagian besar pemakai. Namun demikian laporan keuangan tidak menyediakan semua informasi yang dibutuhkan dalam pengambilan keputusan ekonomi secara umum menggambarkan pengaruh keuangan informasi dari kejadian masa lalu dan tidak diwajibkan menyediakan informasi non keuangan.Pihak manajemen harus bertanggung jawab atas apa yang dilaporkan dalam laporan keuangan artinya pihak manajemen harus membuat laporan itu sesuai dengan kenyataan sebenarnya sehingga laporan keuangan itu memberikan informasi yang dapat dipercaya bagi penggunanya.

\section{Pengembangan Hipotesis}

Menurut penelitian Komang Rudiarsiki, Desak Nyoman Sri Werastuti, Edy Sujana (2015) menyatakan hasil penelitian menunjukan bahwa akuntan pendidikan dan mahasiswa D4/S1 akuntansi memiliki respon baik, namun secara keseluruhan terdapat perbedaan persepsi antara akuntan pendidikan dan mahasiswa D4/S1 akuntansi terhadap etika penyusuna laporan keuangan. Panji Hari Prabowo (2011) menyatakan dalam menguji mahasiswa berdasarkan nilai mean sebesar 56,42 untuk mahasiswa tingkat atas dan 56,67 untuk mahasiswa tingkat bawah dengan nilai signifikasi 0,850. Nilai tersebut memberikan makna rata-rata persepsi antara mahasiswa tingkat bawah dan mahasiswa tingkat atas adalah sama atau tidak terdapat perbedaan persepsi antara kedua kelompok responden dalam mempersepsikan manajemen laba. Data responden yang diberikan mahasiswa tingkat atas dan mahasiswa tingkat bawah yaitu netral cenderung agak setuju. Penelitian Cahyani Siska Dewi (2013) memberikan empiris bahwa terdapat perbedaan antara mahasiswa akuntansi dan mahasiswa manajemen, dimana mahasiswa 
akuntansi memiliki persepsi yang lebih besar mengenai etika penyusunan laporan keuangan. Hal ini disebabkan karena pengetahuan yang dimiliki oleh mahasiswa akuntansi dengan mahasiswa manajemen berbeda, dari segi pengetahuan dan mata kuliah yang ditempuh mahasiswa akuntansi dengan mahasiswa non akuntansi (mahasiswa manajemen). Hasil studi Yulianti dan Fitriany (2005) menyatakan bahwa terjadi perbedaan sikap atas manajemen laba antara program studi dimana program studi S1 reguler akuntansi lebih menolak manajemen laba dibandingkan ketiga program studi lainnya. Sedangkan penelitian Erwin Marfana (2007) menyatakan dalam penelitiannya bahwa tidak ada perbedaan antara mahasiswa akuntansi dan mahasiswa non akuntansi mengenai manajemen laba.

Berdasarkan penelitian terdahulu diatas maka hipotesis dalam penelitian ini adalah sebagai berikut:

$\mathrm{H}_{1}=$ Persepsi mahasiswa akuntansi dan mahasiswa manajemen terhadap etika penyusunan laporan keuangan sangat baik

$\mathrm{H}_{2}=$ Persepsi mahasiswa akuntansi dan mahasiswa manajemen terhadap manajemen laba sangat baik

$\mathrm{H}_{3}=$ Adanya perbedaan persepsi mahasiswa akuntansi dan mahasiswa manajemen terhadap etika penyusunan laporan keuangan

$\mathrm{H}_{4}=$ Adanya perbedaan persepsi mahasiswa akuntansi dan mahasiswa manajemen terhadap manajemen laba

\section{METODE PENELITIAN}

\section{Desain Penelitian}

Desain penelitian ini termaksud dalam penelitian sampel yang ditunjukan untuk mengetahui ada tidaknya persepsi mahasiswa akuntansi dan mahasiswa manajemen mengenai etika penyusunan laporan keuangan dan manajemen laba. Pengambilan data menggunakan survey langsung dan instrument yang digunakan adalah kuesioner (angket). Kuesioner yang digunakan diadopsi oleh peneliti terdahulu dari Yulianti dan Fitriany (2005), Reski (2013) dan ada penambahan oleh Penulis di Manajemen Laba.

\section{Populasi dan Sampel}

Populai penelitian ini adalah mahasiswa akuntansi dan mahasiswa manajemen yang berada di Universitas Muhammadiyah Kupang yang telah atau sedang menempuh 
mata kuliah pengauditan (auditing), akuntansi keuangan, akuntansi pengantar, akuntansi keuangan menengah dan lanjutan, analisa laporan keuangan, serta teori akuntansi yang berjumlah 497 mahasiswa yang terdiri dari 235 mahasiswa akuntansi dan 262 mahasiswa manajemen.

Banyaknya jumlah populasi mahasiswa akuntansi dan mahasiswa manajemen, maka dalam menentukan jumlah sampel yang akan digunakan peneliti menggunakan pedoman kasar (rules of thumb) yang dimukakan oleh Rosces dalam Reski (2013) yaitu

a. Jumlah sampel yang tepat untuk penelitian adalah $30<\mathrm{n}<500$

b. Jika sampel terbagi dalam beberapa subsample maka jumlah sampel minimum untuk setiap sub sampel adalah 30

Berdasarkan uraian diatas, maka peneliti menetapkan jumlah sampel sebanyak 120 orang responden dengan komposisi sebagai berikut;

a. Mahasiswa akuntansi $=60$ responden

b. Mahasiswa manajemen $=60$ responden

\section{Definisi Operasional dan Pengukuran Variabel}

Operasional variabel adalah variabel yang dioperasikan untuk pengujian hipotesis. Agar penelitian ini lebih terarah maka perlu ditentukan variabel yang akan diteliti sebagai berikut:

\begin{tabular}{|c|c|c|c|c|}
\hline Variabel & Definisi Variabel & Indikator & Pengukuran & Skala \\
\hline $\begin{array}{l}\text { Etika } \\
\text { Penyusunan } \\
\text { Laporan } \\
\text { Keuangan }\end{array}$ & $\begin{array}{l}\text { Laporan keuangan adalah } \\
\text { hasil dari proses akuntansi } \\
\text { yang dapat digunakan } \\
\text { sebagai alat untuk } \\
\text { berkomunikasi antara data } \\
\text { keuangan atau aktivitas } \\
\text { perusahaan tersebut. } \\
\text { Penyusunan laporan } \\
\text { keuangan yang sesuai } \\
\text { dengan etika harus } \\
\text { didasarkan pada peraturan } \\
\text { akuntansi yang ada dan yang } \\
\text { terdapat dalam standar } \\
\text { akuntansi keuangan (SAK) } \\
\text { Reski (2013). }\end{array}$ & $\begin{array}{ll}\text { 1. } & \text { Misstate } \\
\text { 2. } & \text { Disclosure } \\
\text { 3. } & \text { Cost \& } \\
& \text { Benefit } \\
\text { 4. } & \text { Responsibili } \\
\text { ty }\end{array}$ & $\begin{array}{l}\text { Skala } 5 \text { (sangat } \\
\text { setuju), } 4 \text { (setuju), } \\
3 \text { (ragu-ragu), } 2 \\
\text { (tidak setuju), } \\
\text { 1(sangat tidak } \\
\text { setuju) }\end{array}$ & Likter \\
\hline
\end{tabular}




\begin{tabular}{|c|c|c|c|c|}
\hline $\begin{array}{l}\text { Manajemen } \\
\text { Laba }\end{array}$ & $\begin{array}{l}\text { Manajemen laba merupakan } \\
\text { suatu fenomena baru yang } \\
\text { telah menambah wacana } \\
\text { perkembangan teori } \\
\text { akuntansi Yulianti \& Fitriany } \\
\text { (2005) }\end{array}$ & $\begin{array}{l}\text { Manajemen } \\
\text { laba dalam } \\
\text { laporan } \\
\text { keuangan } \\
\text { dengan } \\
\text { indikator } \\
\text { pengambilan } \\
\text { keputusan } \\
\text { dalam sebuah } \\
\text { perusahaan } \\
\text { yang sedang } \\
\text { mengelami } \\
\text { kesulitan } \\
\text { keuangan dan } \\
\text { berusaha } \\
\text { meningkatkan } \\
\text { laba dan } \\
\text { ketepatan } \\
\text { waktu dalam } \\
\text { penyajian } \\
\text { informasi } \\
\text { keuangan. } \\
\text { 1. Teknik } \\
\text { income } \\
\text { maxization } \\
\text { 2. Teknik } \\
\text { income } \\
\text { minization } \\
\text { 3. Teknik } \\
\text { income } \\
\text { taking a } \\
\text { bast } \\
\text { 4. Teknik } \\
\text { income } \\
\text { smoothing. }\end{array}$ & $\begin{array}{l}\text { Skala } 5 \text { (sangat } \\
\text { setuju), } 4 \text { (setuju), } \\
3 \text { (ragu-ragu), } 2 \\
\text { (tidak setuju), } \\
\text { 1(sangat tidak } \\
\text { setuju) }\end{array}$ & likert \\
\hline
\end{tabular}

\section{Uji Hipotesis}

Setelah data dikumpulkan dan diuji validitas dan reliabilitas, maka selanjutnya dilakukan pengujian yang berhubungan dengan model statistic yang akan digunakan dalam pengujian hipotesis. Alat analisa untuk menguji hipotesis-hipotesis tersebut digunakan adalah analisis regresi berganda (mulipleregression) pengolahan data dilakukan dengan pendekatan SPSS release 21 for windows. Untuk menguji hipotesis yang telah ditetapkan apakah diterima atau ditolak. 
a. Uji simultan

$\mathrm{F}_{\text {hitung }}=\frac{\left(R X 1, X 2_{1},\right)^{2}(n-m-1)}{m\left(1-R^{2} X 1, X 2, Y\right)}$

Sumber: Siregar (2013)

keterangan:

$$
\begin{aligned}
& \mathrm{m}=\text { jumlah variabel bebas } \\
& \mathrm{n}=\text { jumlah responden }
\end{aligned}
$$

b. Uji Parsial

$$
t_{\text {hitung }}=\frac{b i}{S b i}
$$

Sumber: Siregar (2013)

keterangan:

$$
\begin{aligned}
& \text { bi }=\text { nilai konstanta } \\
& S_{b i}=\text { standar error }
\end{aligned}
$$

\section{HASIL PENELITIAN DAN PEMBAHASAN}

\section{Rincian pengembalian kuesioner}

Metode pengumpulan data dalam penelitian ini adalah penelitian lapangan (field research), yaitu metode pengumpulan data yang dilakukan denga cara pembagian kuesioner secara langsung kepada objek. Hasil penyebaran kuesioner untuk masingmasing sampel disajikan dalam tabel berikut ini.

\begin{tabular}{ccccc} 
No & Kelompok & $\begin{array}{c}\text { Kuesioner } \\
\text { Disebarkan }\end{array}$ & $\begin{array}{c}\text { Kuesioner } \\
\text { Kembali }\end{array}$ & $\begin{array}{c}\text { Tingkat } \\
\text { Pengembalian }\end{array}$ \\
\hline 1. & Mahasiswa Akuntansi & 60 & 50 & $83,3 \%$ \\
2. & Mahasiswa Manajemen & 60 & 51 & $85 \%$ \\
\hline
\end{tabular}

Sumber; Data diolah penulis 2016

\section{Hasil jawaban responden}

Gambaran ini akan menyajikan gambaran mengenai kuesioner yang telah disebarkan kepada para mahasiswa/I akuntansi dan manajemen di Universitas Muhammadiyah Kupang. 
a. Presentase jawaban responden variabel persepsi mahasiswa akuntansi terhadap etika penyusunan laporan keuangan

Penyebaran kuesioner data hasil jawaban responden mahasiswa akuntansi terhadap etika penyusunan laporan keuangan maka dapat dijelaskan beberapa persepsi mahasiswa akuntansi tentang etika penyusunan laporan keuangan yaitu jawaban respoonden tertinggi terdapat pada kategori jawaban Setuju sebesar 367\%, yang dikuti dengan jawaban Ragu-ragu sebesar 150\%, jawaban Tidak Setuju 140\%, jawaban Sangat Tidak Setuju 96\% dan jawaban Sangat Setuju 55\%.

b. Presentase jawaban responden variabel persepsi mahasiswa akuntansi terhadap manajemen laba

Penyebaran kuesioner data hasil jawaban mahasiswa akuntansi terhadap manajemen laba maka dapat dijelaskan beberapa pendapat responden tentang variabel manajemen laba yaitu jawaban responden tertinggi terdapat pada kategori jawaban Setuju sebesar 65\%, diikuti dengan jawaban Tidak Setuju sebesar 50\%, jawaban Raguragu sebesar 39\%, jawaban Sangat Tidak Setuju sebesar 37\% dan Sangat Setuju sebesar $19 \%$.

c. Presentase jawaban responden variabel persepsi mahasiswa manajemen terhadap etika penyusunan laporan keuangan

Penyebaran hasil jawaban kuesioner persepsi mahasiswa manajemen terhadap etika penyusunan laporan keuangan maka yang dapat dijelaskan beberapa pendapat responden tentang etika penyusunan laporan keuangan yaitu jawaban responden tertinggi Setuju sebesar 233\%, yang dikuti dengan jawaban Tidak Setuju 199\%, jawaban Sangat Tidak setuju 138\%, jawaban Sangat Setuju sebesar 124\% dan jawaban Ragu-ragu sebesar $122 \%$.

d. Presentase jawaban responden variabel persepsi mahasiswa manajemen terhadap manajemen laba

Penyebaran data hasil jawaban persepsi mahasiswa manajemen terhadap manajemen laba maka dapat dijelaskan beberapa pendapat responden tentang manajemen laba yaitu jawaban responden tertinggi Setuju sebesar $72 \%$, yang diikuti dengan jawaban responden Tidak Sejutu sebesar 42\%, jawaban Sangat Setuju 40\%, jawaban Ragu-ragu sebesar 30\% dan jawaban Sangat Tidak Setuju sebesar $20 \%$. 


\section{Pembahasan}

1. Persepsi mahasiswa akuntansi dan mahasiswa manajemen terhadap etika penyusunan laporan keuangan

Dari hasil rekapitulasi jawaban responden mahasiswa akuntansi terdapat total skor untuk sangat tidak setuju (STS) sebesar 96, tidak setuju (TS) sebesar 140, raguragu (RR) sebesar 150, setuju (S) sebesar 367 dan sangat setuju (SS) sebesar 55 sedangkan mahasiswa manajemen total skor tidak sangat setuju (STS) sebesar 138, tidak setuju (TS) sebesar 199, ragu-ragu (RR) sebesar 122, setuju (S) sebesar 233 dan sangat setuju (SS) 124. Dengan demikian maka persepsi mahasiswa akuntansi dan mahasiswa manajemen terhadap etika penyusunan laporan keuangan dapat dikatakan baik. Etika penyusunan laporan keuangan terdiri dari 4 sub variabel yaitu misstate, disclosure, cost and benefit dan responsibility.

a. misstate

Persepsi mahasiswa akuntansi dan mahasiswa manajemen terhadap misstate dapat dikatakan baik. Semakin rendah jumlah skor jawaban responden semakin rendah mahasiswa terhindar dari melakukan misstate dalam laporan keuangan. Hasil jawaban presentase mahasiswa akuntansi sebesar 34\% dan mahasiswa manajemen sebesar $35.2 \%$ ini ditunjukan pada pertanyaan no 1 . Hal ini disebabkan karena mahasiswa akuntansi lebih tidak menyetujui melakukan misstate yang disengaja sedangkan mahasiswa manajemen lebih menyetujui melakukan misstate dalam laporan keuangan karena hal ini dapat menyelamatkan perusahaan dari kebangkrutan.

\section{b. disclosure}

Persepsi mahasiswa akuntansi dan mahasiswa manajemen terhadap disclosure dapat dikatakan baik. Semakin tinggi jumlah skor jawaban responden semakin tinggi mahasiswa melakukan pengungkapan informasi dalam laporan keuangan. Hasil jawaban presentase mahasiswa akuntansi sebesar 54\% dan mahasiswa manajemen sebesar $27.4 \%$ ini ditunjukan pada pertanyaan no 5. Hal ini disebabkan karena mahasiswa akuntansi dan mahasiswa manajemen sama-sama memiliki tanggung jawab yang baik dalam pengungkapan informasih dalam laporan keuangan walaupun terdapat perbedaan yang signifikan.

c. Cost and benefit 
Persepsi mahasiswa akuntansi dan mahasiswa manajemen terhadap cost and benefit dapat dikatakan baik. Hasil jumlah skor jawaban responden semakin tinggi menggambarkan persepsi yang lebih baik dalam memandang pengungkapan bukan sebagai beban, melainkan sebagai suatu keharusan. Hasil presentase jawaban responden mahasiswa akuntansi sebesar 54\% dan mahasiswa manajemen sebesar 23,5\%. Hal ini disebabkan karena mahasiswa memandang dari sisi banyaknya aturan-aturan akuntansi yang kompleks dan harus mempublikasikan informasi yang sangat luas.

\section{d. Responsibility}

Persepsi mahasiswa akuntansi dan mahasiswa manajemen terhadap responsibility dapat dikatakan baik. Jumlah skor jawaban responden tertinggi mengambarkan tanggung jawab yang lebih tinggi untuk menyajikan laporan keuangan yang informative bagi penggunanya. Hasil presentase jawaban responden mahasiswa akuntansi sebesar 50\% dan mahasiswa manajemen sebesar 33.3\%. Hal ini disebabkan karena mahasiswa akuntansi memiliki tanggung jawab yang lebih tinggi dalam penyajian laporan keuangan dibandingkan mahasiswa manajemen walaupun tidak terdapat perbedaan secara signifikan

2. Persepsi mahasiswa akuntansi dan mahasiswa manajemen terhadap manajemen laba sangat baik

Hasil yang diperoleh dari rekapitulasi jawaban responden mahasiswa akuntansi dan mahasiswa manajemen terhadap manajemen laba menujukan bahwa persepsi mahasiswa akuntansi dan mahasiswa manajemen mempunyai respon yang baik. Dari hasil rekapitulasi jawaban responden mahasiswa akuntansi terdapat total skor untuk sangat Adanya perbedaan persepsi mahasiswa akuntansi dan mahasiswa manajemen terhadap etika penyusunan laporan keuangan

Berdasarkan hasil pengujian dengan pengujian hipotesis dengan metode non parametric yaitu mann whitney test terdapat perbedaan signifikan mahasiswa akuntansi dan mahasiswa manajemen nilai probabilitas lebih kecil dari 0.05 yang berarti adanya perbedaan persepsi mahasiswa akuntansi dan mahasiswa manajemen terhadap etika penyusunan laporan keuangan, sedangkan nilai probabilitas lebih besar dari 0.05 yang berarti tidak adanya perbedaan persepsi mahasiswa akuntansi dan mahasiswa manajemen terhadap etika penyusunan laporan keuangan. 
Persepsi mahasiswa akuntansi dan mahasiswa manajemen terhadap manajemen laba dapat dikatakan baik. Hasil jawaban semakin rendahjumlah skor semakin rendah mahasiswa terhindar dari tindakan melakukan manjemen laba. Hasil presentase jawaban responden mahasiswa akuntansi sebesar $65 \%$ dan mahasiswa manajemen sebesar $72 \%$. Hal ini sebebkan karena mahasiswa akuntansi lebih menolak manajemen laba dan melaporakan kondisi sebenarnya sedangkan mahasiswa manajemen lebih menyetujui manajemen laba karena mahasiswa manajemen lebih memilih menyelamatkan perusahaan yang sedang mengelami krisis ekonomi dengan mengeser asset-asset bahkan sampai minus.

Berdasarkan hasil dari keseluruhan 16 pertanyaan pada mahasiswa akuntansi dan mahsiswa manajemen terdapat perbedaan nilai rata-rata mean rank persepsi mahasiswa akuntansi (51.43) lebih besar nilai mean rank persepsi mahasiswa manajemen (50.58). Selain dilihat dari mean rank dapat dilihat hasil pengujian test statistic terhadap persepsi mahasiswa akuntansi dan persepsi mahasiswa manajemen menujukan bahwa pada kolom asymp. Sig. (2-tailed) / asymptotic significance untuk uji dua sisi adalah 0.884 , atau probabilitas diatas $0.05(0.884>0.05)$ ini berarti hipotesis diterima. Ini berarti tidak terdapat perbedaan persepsi mahasiswa akuntansi dan mahasiswa manajemen terhadap etika penyusunan laporan keuangan.

3. Adanya perbedaan persepsi mahasiswa akuntansi dan mahasiswa manajemen terhadap manajemen laba.

Adanya perbedaan persepsi mahasiswa akuntansi dan mahasiswa manajemen terhadap manajemen laba. Semakin rendah jumlah hasil jawaban responden semakin semakin rendah mahasiswa terhindar dari tindakan melakukan manajemen laba. Hasil pengujian menujukan mahasiswa akuntansi sebesar (44.52) dan mahasiswa manajemen sebesar (57.35). Persepsi mahasiswa akuntansi lebih rendah dibandingkan mahasiswa manajemen. Perbedaan ini disebabkan mahasiswa akuntansi lebih memilih mengungkapkan informasi kondisi perusahaan yang sebenarnya dibandingkan mahasiswa manajemen lebih memilih melakukan manajemen laba karena lebih menyelamatkan perusahaan yang sedang mengelami krisis ekonomi. 


\section{Kesimpulan}

Berdasarkan pembahasan dapat disimpulkan beberapa kesimpulan sebagai berikut;

1. Persepsi mahasiswa akuntansi dan mahasiswa manajemen terhadap etika penyusunan laporan keuangan adalah baik. Hal ini disebabkan mahasiswa samasama memiliki kecenderungan yang baik dalam pengukapan informasi dalam laporan keuangan;

2. Persepsi mahasiswa akuntansi dan mahasiswa manajemen dapat adalah baik. Hal ini disebabkan mahasiswa akuntansi memiliki kecenderungan yang baik dalam mengungkapan informasi dalam laporan keuangan dan memilih mengungkapan informasi kondisi perusahaan yang sebenarnya, sedangkan mahasiswa manajemen lebih menyetujui manajemen laba karena ingin menyelamatkan perusahaan yang sedang mengelami krisis ekonomi.

3. Tidak terdapat perbedaan Persepsi mahasiswa akuntansi dan mahasiswa manajemen terhadap etika penyusunan laporan keuangan meskipun terdapat perbedaan rata-rata namun tidak terdapat perbedaan secara statistic;

4. Adanya perbedaan persepsi mahasiswa akuntansi dan mahasiswa manajemen terhadap manajemen laba. Hal ini disebabkan karena mahasiswa akuntansi memilih mengungkapkan kondisi perusahaan yang sebenarnya dibandingkan mahasiswa manajemen lebih menyelamatkan perusahaan dari krisis ekonomi.

\section{Keterbatasan}

Penelitian ini hanya meneliti persepsi mahasiswa akuntansi dan mahasiswa manajemen terhadap etika penyusunan laporan keuangan dan manajemen laba di Universitas Muhammadiyah kupang. Metode pengujian dalam penelitian ini menggunakan pengujian non parametric yaitu mann whiney test dan pengujian perbandingan anova yaitu one way anova.

\section{Saran}

Berdasarkan hasil penelitian dan kesimpulan maka saran-saran yang diberikan adalah

1. Penelitian selanjutnya bukan hanya menggunakan metode pengumpulan data yaitu dengan sistem kuesioner saja akan tetapi juga menggunakan sistem wawancara pada responden; 
2. Penelitian selanjunya tidak hanya terbatas pada satu universitas tetapi juga melakukan perbandingan dengan universitas lainnya seperti universitas negeri maupun universitas swasta dan sekolah tinggi lainnya;

3. Responden selanjutnya tidak hanya terbatas pada mahasiswa akuntansi dan mahasiswa manajemen tetapi juga melakukan perbandingan dengan akuntan public maupun dosen-dosen akuntansi lainnya yang berada di kota kupang.

\section{Daftar Pustaka}

Cahaya, Siska Dewi, 2013. "Perbedaan Persepsi Mahasiswa Akuntansi Dengan Mahasiswa Manajemen Terhadap Etika Penyusunan Laporan Keuangan “ Skripsi. Jurusan Akutansi Program S1. Universitas Pendidikan Ganesha Singaraja. Bali

Clikeman, P. M. \& S. L. Henning, 2000. "The Socialization Of Undergradue Accounting Education" Vol 15, PP. 1-15.

Daito, Appollo, 2004. “Jurnal Penelitian Akuntansi Pendekatan Positif Dan Normative, Program Pascasarjana Magister Akuntansi Fakultas Ekonomi." Universitas Budi Luhur. Jakarta

IAI, 2007. “Standar Akuntansi Keuangan”. Selemba Empat. Jakarta

Komang Rudiarsiki, Desak Nyoman Sri Werastuti,Edy Sujana 2015 “Persepsi Akuntan Pendidikan Dan Mahasiswa Akuntansi Terhadap Etika Penyusunan Laporan Keuangan” Universitas Pendidikan Ganesah Singaraja. Bali

Panji Hari Prabowo, 2011. "Persepsi Mahasiswa Akuntansi Mengenai Etika Penyusunan Laporan Keuangan”. Skripsi. Universitas Negeri Semarang

Reski, 2013. "Perbandingan Persepsi Akuntan Dan Mahasiswa Akuntansi Terhadap Etika Penyusunan Laporan Keuangan" Universitas Hasanuddin Makassar

Setiadi Nugroho J. 2003. “Perilaku Konsumen”. Kencana. Jakarta

Wulandari Dan Sularso. 2002. “Kecukupan Muatan Etika Dalam Pendidikan Akuntansi" SNA

Yulianti Dan Fitrsiany. 2005 "Persepsi Mahasiswa Akuntansi Terhadap Etika Penyusunan Laporan Keuangan" Simposium Nasional Akuntansi VIII 